\title{
Analisis Kebutuhan Belajar Bahasa Inggris Berbasis English for Specific Purposes pada Mahasiswa Fakultas Teknik Universitas Negeri Gorontalo
}

\author{
Helena Badu \\ Sri Widyarti Ali \\ Magvirah El Walidayni Kau \\ Universitas Negeri Gorontalo \\ Pos-el: helenabadu@ung.ac.id \\ widyartiali@ung.ac.id \\ magvirahelwalidayni@ung.ac.id
}

\section{DOI: 10.32884/ideas.v6i4.308}

\begin{abstract}
Abstrak
Pembelajaran bahasa Inggris bagi mahasiswa di jurusan nonkependidikan semestinya didasarkan pada hasil analisis kebutuhan belajar agar mahasiswa dapat memperoleh manfaat belajar bahasa Inggris sesuai kebutuhan mereka. Akan tetapi, kenyataannya pembelajaran bahasa Inggris selama ini tidak didasarkan pada kebutuhan belajar mahasiswa. Berdasarkan hal tersebut, maka penelitian ini bertujuan untuk menganalisis kebutuhan belajar bahasa Inggris pada mahasiswa di lima program studi yang ada di Fakultas Teknik Universitas Negeri Gorontalo, yaitu prodi Elektro, Arsitektur, Sipil, Industri, dan Informatika. Pengumpulan data dilaksanakan melalui pemberian angket kepada mahasiswa Fakultas Teknik sebagai responden penelitian untuk mengidentifikasi apa saja kebutuhan dan harapan mahasiswa dalam belajar bahasa Inggris di prodi mereka. Hasil penelitian menunjukkan bahwa mahasiswa di Fakultas Teknik memiliki kebutuhan belajar bahasa Inggris yang dititikberatkan pada peningkatan empat keterampilan bahasa, yaitu berbicara, menulis, mendengar, dan membaca. Selain itu, mahasiswa juga memiliki harapan untuk dapat lebih banyak belajar kosakata bahasa Inggris yang berhubungan dengan program studi mereka karena kosakata tersebut sangat membantu mereka dalam proses pembelajaran mata kuliahmata kuliah di prodi mereka. Hasil penelitian ini diharapkan dapat menjadi acuan bagi dosen pengajar dalam menyusun silabus dan bahan ajar mata kuliah bahasa Inggris di prodi-prodi yang ada di Fakultas Teknik UNG.
\end{abstract}

\section{Kata Kunci}

Analisis kebutuhan, english for specific purposes, fakultas teknik

\begin{abstract}
The English learning for students in non-educational majors should be based on students' learning needs analysis, so that students can benefit from learning English according to their needs. However, the reality shows that the English learning so far is not based on the learning needs of students. Therefore, this study aims to analyze the English learning needs of students in five study programs in the Engineering Faculty of Gorontalo State University, namely the Electrical, Architecture, Civil, Industrial and Informatics study programs. The data collection was carried out through giving questionnaires to the students to identify the needs and the expectations of them in learning English in their study programs. The results revealed that the
\end{abstract}

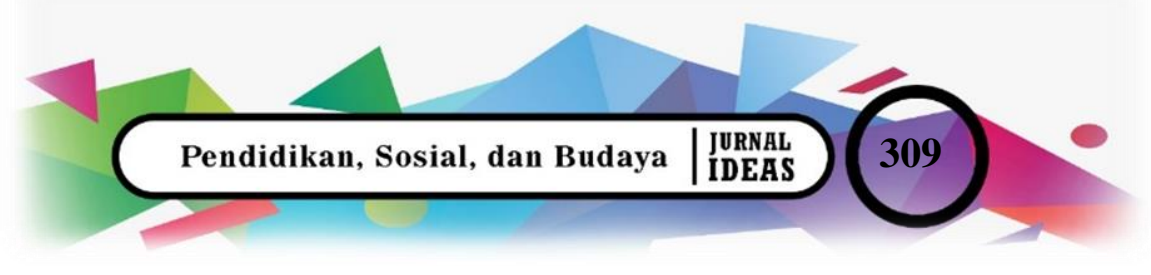


students in the engineering faculty have a need to learn English which is focused on improving four language skills, namely speaking, writing, listening, and reading. In addition, students also have the expectation of being able to learn more English vocabulary related to their fields of study, because the vocabulary really helps them in the learning process of the subjects in their study programs. The result of this study is expected to be a reference for the lecturers in compiling syllabus and teaching materials of English course in those five study programs at the Faculty of Engineering, UNG.

Keywords

Needs analysis, english for specific purposes, engineering faculty

\section{Pendahuluan}

Bahasa Inggris merupakan salah satu mata kuliah umum yang wajib diikuti oleh setiap mahasiswa di Universitas Negeri Gorontalo. Mata kuliah ini bertujuan untuk membekali para peserta didik dengan kemampuan berbahasa Inggris untuk kepentingan jangka pendek maupun jangka panjang. Manfaat jangka pendek dari pembelajaran bahasa Inggris adalah membekali para mahasiswa dengan keterampilan berbahasa Inggris yang dapat membantu dan mempermudah mereka dalam proses belajar mata kuliah-mata kuliah khusus yang ada di program studi (prodi) mereka. Sementara itu, manfaat jangka panjang pembelajaran bahasa Inggris adalah untuk menunjang dan menciptakan lulusan berkualitas dan mampu bersaing dalam dunia kerja.

Mata kuliah bahasa Inggris yang diajarkan pada mahasiswa selain program studi bahasa Inggris adalah berupa bahasa Inggris bertujuan khusus atau English for Specific Purposes (ESP). Sesuai dengan istilah specific atau khusus yang digunakan di dalamnya, maka tujuan dari pengajaran bahasa Inggris berbasis ESP tersebut akan bermuara pada penguasaan keterampilan bahasa Inggris yang spesifik pada bidang ilmu tertentu. Kusumaningputri (2010: 5) menyatakan bahwa salah satu manfaat dari English for Specific Purposes adalah agar mahasiswa dapat belajar menggunakan bahasa Inggris langsung pada konteks disiplin ilmu mereka baik untuk kepentingan akademis dan nonakademis. Dengan kata lain, bahasa Inggris pada ESP dapat menunjang pengetahuan mahasiswa terhadap bidang ilmu di prodi yang mereka pilih. Oleh karenanya, penyusunan silabus dan materi ajar dalam mata kuliah bahasa Inggris pun harus sesuai dengan kebutuhan mahasiswa di prodi yang diajar.

Permasalahan yang ada saat ini adalah penggunaan silabus dalam pengajaran bahasa Inggris di lingkungan Universitas Negeri Gorontalo masih jauh dari hakikat English por Specific Purposes tersebut. Dengan kata lain, materi-materi yang tertera di silabus masih bersifat umum dan tidak berdasarkan bidang ilmu di prodi para peserta didik. Tentunya, 


Volume : 6
Nomor : 4
Bulan : November
Tahun : 2020

keterampilan dan komponen bahasa yang termuat di dalamnya pun masih bersifat umum dan tidak mampu memenuhi kebutuhan mahasiswa sesuai dengan prodi yang mereka pilih. Selain itu, terdapat ketidakseragaman silabus pada para pengajar menyebabkan adanya muatan pengetahuan bahasa Inggris yang berbeda-beda pula pada mahasiswa.

Berdasarkan permasalahan inilah, maka dipandang perlu untuk diadakan suatu analisis terhadap kebutuhan penggunaan bahasa Inggris pada mahasiswa sesuai dengan program studi mereka. Dalam hal ini, yang dipilih adalah prodi-prodi yang ada di Fakultas Teknik, yaitu prodi Elektro, Arsitektur, Sipil, Industri, dan Informatika. Dengan melaksanakan penelitian tentang analisis kebutuhan belajar mahasiswa, maka dosen pengajar dapat memperoleh acuan dalam menentukan topik-topik pembelajaran bahasa Inggris di fakultas teknik, juga dapat melahirkan silabus dan bahan ajar yang benar-benar sesuai dengan kebutuhan belajar mahasiswa. Sebagaimana penelitian sebelumnya berjudul "Analisa Kebutuhan (Need Analysis) Mata Kuliah Bahasa Inggris untuk Mahasiswa Kejuruan” yang dilaksanakan oleh Mita Nur Aflah dan Eka Fajar Rahmani (2018) menunjukkan bahwa mahasiswa membutuhkan kemampuan berbicara secara lancar dan komunikatif dalam rangka persiapan diri memenuhi tuntutan profesi mereka ke depannya. Hal tersebut menunjukkan bahwa keinginan mahasiswa yang mengarah pada peningkatan kemampuan berbicara (speaking) ini sudah sangat sesuai dengan kebutuhan pasar kerja yang mensyaratkan kemampuan berkomunikasi dalam bahasa Inggris dengan baik.

Studi lainnya pernah dilaksanakan oleh Rita Karmila Sari (2019) dengan judul "Analisis Kebutuhan Pembelajaran Bahasa Inggris pada Mahasiswa Kelas Karyawan” yang mengungkapkan bahwa motivasi mahasiswa dalam mempelajari bahasa Inggris adalah untuk membantu meningkatkan nilai akademik dan agar mereka mampu berbicara dalam bahasa Inggris, sedangkan kendala utama mereka adalah keterbatasan kosakata dan tidak memahami tata bahasa dalam bahasa Inggris. Hasil analisis kebutuhan pembelajaran bahasa Inggris menyimpulkan bahwa mahasiswa membutuhkan bahasa Inggris untuk memahami teks dan instruksi, serta memperoleh informasi yang bermanfaat bagi studi mereka.

Berdasarkan kedua literatur tersebut, maka jelas bahwa analisis kebutuhan memiliki peran penting di dalam pembelajaran karena melalui analisis kebutuhan, dosen, mahasiswa sebagai peserta didik, silabus, bahan ajar, metode pembelajaran, semua dapat terhubung dengan harmonis guna meningkatkan kualitas pembelajaran di dalam kelas. Olehnya, hasil studi ini dapat dijadikan acuan bagi perancangan silabus mata kuliah bahasa Inggris berbasis English for 
Specific Purposes di prodi Elektro, Arsitektur, Sipil, Industri, dan Informatika Universitas Negeri Gorontalo.

\section{Metode}

Penelitian ini dilaksanakan di fakultas teknik Universitas Negeri Gorontalo (UNG). Penelitian dilaksanakan dengan cara mengidentifikasi kebutuhan belajar mahasiswa dengan menggunakan angket. Kegiatan ini diawali dengan pembuatan angket berdasarkan indikator pengidentifikasian kebutuhan belajar mahasiswa. Selanjutnya, penyebaran angket yang diisi oleh mahasiswa. Tidak semua mahasiswa dilibatkan dalam pengisian angket. Namun, mengambil sampel dengan menggunakan random sampling. Hal ini dilakukan untuk memudahkan peneliti dalam analisis hasil angket, serta mengefisienkan waktu juga dengan pertimbangan banyaknya jumlah mahasiswa pada masing-masing program studi di fakultas teknik.

Dari hasil identifikasi dan analisis angket diperoleh kesimpulan mengenai kebutuhan belajar Bahasa Inggris mahasiswa di fakultas Teknik UNG. Hasil analisis kebutuhan belajar ini nantinya dapat dijadikan sebagai acuan dalam penyusunan silabus dan bahan ajar mata kuliah bahasa Inggris di Fakultas Teknik Universitas Negeri Gorontalo.

\section{Hasil dan Pembahasan}

Penyebaran angket kebutuhan belajar (need analysis) mahasiswa bertujuan untuk memperoleh informasi mendalam mengenai kebutuhan belajar bahasa Inggris mahasiswa di Fakultas Teknik Universitas Negeri Gorontalo. Sebagaimana yang dinyatakan oleh Casper (2003) bahwa analisis kebutuhan merupakan rangkaian kegiatan untuk mengumpulkan informasi tentang kebutuhan, keinginan, dan harapan belajar siswa. Adapun hasil analisis angket kebutuhan belajar mahasiswa ini kemudian dapat dijadikan panduan dalam penyusunan silabus mata kuliah bahasa Inggris berbasis English for Specific Purposes di prodi-prodi yang ada di Fakultas Teknik. Penyusunan silabus yang didasarkan pada hasil analisis kebutuhan belajar peserta didik diyakini dapat menjadi solusi bagi masalah-masalah dalam pembelajaran, khususnya bahasa Inggris bagi mahasiswa di prodi nonkependidikan. Hal ini didukung oleh Heredia (dalam Mohammed, 2012: 250) bahwa, "ESP is a branch of teaching English as a second language according to the needs of the learner and similar to this is the syllabus which must address the specific needs of the learner." 
Volume : 6

Nomor : 4

E-ISSH: 2656-940X

Bulan : November

Tahun : 2020

P-ISSH: 2442-367K

URL: jurnal.ideaspublishing.co.id 


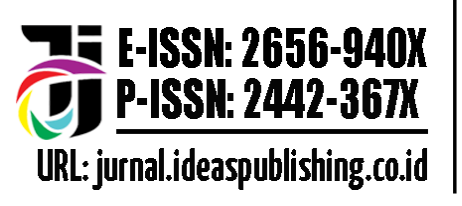

Volume : 6

Nomor : 4

Bulan : November

Tahun : 2020

Fakultas Teknik memiliki lima program studi nonkependidikan, yaitu prodi Elektro, Arsitektur, Sipil, Industri, dan Informatika. Berikut adalah hasil analisis kebutuhan belajar mahasiswa di prodi-prodi Fakultas Teknik UNG. Hasil analisis angket ini diklasifikasikan berdasarkan language skills, language components, metode/strategi pembelajaran, dan topik yang disarankan oleh mahasiswa sebagai responden.

Tabel 1 Hasil Analisis Kebutuhan Belajar Mahasiswa Prodi Teknik Elektro

\begin{tabular}{|c|c|c|c|}
\hline $\begin{array}{l}\text { LANGUAGE } \\
\text { SKILLS (\%) }\end{array}$ & $\begin{array}{c}\text { LANGUAGE } \\
\text { COMPONENTS } \\
(\%)\end{array}$ & METODE/ STRATEGI & $\begin{array}{l}\text { TOPIK YANG } \\
\text { DISARANKAN }\end{array}$ \\
\hline $\begin{array}{l}\text { Listening }(100 \%) \\
\text { Speaking }(100 \%) \\
\text { Reading }(100 \%) \\
\text { Writing }(94 \%)\end{array}$ & $\begin{array}{l}\text { 1. Grammar }(94 \%) \\
\text { 2. Vocabulary yang } \\
\text { berhubungan } \\
\text { dengan prodi } \\
(100 \%)\end{array}$ & $\begin{array}{l}\text { 1. } \text { Ceramah/lecture }(65 \%) \\
\text { 2. Memberi latihan }(88 \%) \\
\text { 3. Diskusi kelas }(71 \%) \\
\text { 4. } \text { Bermain peran }(59 \%) \\
\text { 5. } \text { Melaksanakan tugas } \\
\text { berkelompok/berpasangan } \\
(82 \%) \\
\text { 6. Melaksanakan tugas } \\
\text { secara individu }(71 \%) \\
\text { 7. Lagu/film/game }(82 \%)\end{array}$ & $\begin{array}{l}\text { 1. Mikro prosesor } \\
\text { 2. Modul come lab } \\
\text { 3. Medan elektromaknetik } \\
\text { 4. Control } \\
\text { 5. Elektronik daya } \\
\text { 6. Sistem linear } \\
\text { 7. Metode numeric } \\
\text { 8. Aplikasi c plus } 2 \\
\text { 9. Control robotic } \\
\text { 10. Menulis } \\
\text { 11. Grammar } \\
\text { 12. Tegangan tinggi } \\
\text { 13. Hukum gaus } \\
\text { 14. Divergensi } \\
\text { 15. Istilah dalam fisika }\end{array}$ \\
\hline
\end{tabular}

Hasil analisis angket di Program Studi Elektro menunjukkan bahwa pada aspek keterampilan bahasa, seluruh responden (100\%) setuju bahwa pengajaran bahasa Inggris bertujuan untuk meningkatkan keterampilan mendengar (listening), berbicara (speaking), dan membaca (reading), dan sebanyak 94\% responden setuju untuk meningkatkan kemampuan menulis dalam pembelajaran bahasa Inggris. Hal ini berbanding lurus dengan ekspektasi mahasiswa terhadap muatan language component dalam silabus, yaitu 94\% menganggap bahwa pembelajaran grammar penting. $100 \%$ responden setuju bahwa melalui pembelajaran bahasa Inggris mahasiswa dapat meningkatkan penguasaan kosakata atau terminologi yang berhubungan dengan bidang ilmu mereka.

Pada aspek selanjutnya, yaitu metode/strategi pembelajaran, sebanyak $88 \%$ responden setuju bahwa pembelajaran bahasa Inggris diimplementasikan melalui pemberian latihan/praktik penggunaan bahasa. $65 \%$ responden setuju dengan pembelajaran menggunakan metode ceramah. Hal ini mengindikasikan bahwa mahasiswa pada Prodi Elektro memiliki ekspektasi bahwa kegiatan pembelajaran bahasa Inggris di prodi mereka 
Volume : 6

Nomor : 4

Bulan : November

Tahun : 2020
E-ISSH: 2656-940X

P-ISSH: 2442-367K

URL: jurnalideaspublishing.co.id

lebih didominasi oleh latihan/praktik penggunaan bahasa daripada pemberian teori dalam perkuliahan. Selain itu, sebanyak $71 \%$ responden setuju untuk melaksanakan kegiatan pembelajaran bahasa Inggris dengan metode diskusi, dan dengan jumlah yang sama mereka setuju melaksanakan tugas-tugas secara individu. Sebanyak $82 \%$ responden setuju melaksanakan kegiatan pembelajaran secara berkelompok, dan dengan persentase yang sama mereka setuju bahwa kegiatan pembelajaran dilaksanakan dengan menggunakan teknik pembelajaran berupa lagu, film, atau permainan. Jumlah persentase yang paling rendah adalah pada metode pembelajaran bermain peran, yakni hanya 59\% dari jumlah responden yang setuju dengan penggunaan metode ini. Berdasarkan hasil persentase ini, dapat disimpulkan bahwa sebagian besar mahasiswa di Prodi Elektro memiliki ekspektasi kegiatan pembelajaran bahasa Inggris dilaksanakan dengan menggunakan media/metode pembelajaran berupa lagu, film, atau permainan, dan tugas-tugas kelas dapat diselesaikan dengan cara berpasangan ataupun berkelompok. Hal ini bertujuan untuk memudahkan para peserta didik untuk memahami materi pembelajaran, serta dapat dengan mudah melaksanakan tugas-tugas yang diberikan dosen. Selain itu, dengan melaksanakan tugas berkelompok, mereka dapat mendiskusikan hal-hal yang tidak dipahami dengan teman.

Tabel 2 Hasil Analisis Kebutuhan Belajar Mahasiswa Prodi Teknik Arsitektur

\begin{tabular}{|c|c|c|c|}
\hline $\begin{array}{l}\text { LANGUAGE } \\
\text { SKILLS (\%) }\end{array}$ & $\begin{array}{c}\text { LANGUAGE } \\
\text { COMPONENTS }(\%)\end{array}$ & METODE/ STRATEGI & $\begin{array}{l}\text { TOPIK YANG } \\
\text { DISARANKAN }\end{array}$ \\
\hline $\begin{array}{l}\text { Listening }(100 \%) \\
\text { Speaking }(100 \%) \\
\text { Reading }(93 \%) \\
\text { Writing }(100 \%)\end{array}$ & $\begin{array}{l}\text { 1. } \text { Grammar }(100 \%) \\
\text { 2. Vocabulary yang } \\
\text { berhubungan dengan } \\
\text { prodi }(100 \%)\end{array}$ & $\begin{array}{l}\text { 1. Ceramah/lecture }(93 \%) \\
\text { 2. Memberi latihan }(100 \%) \\
\text { 3. Diskusi kelas }(80 \%) \\
\text { 4. Bermain peran }(73 \%) \\
\text { 5. Melaksanakan tugas ber- } \\
\text { kelompok/berpasangan } \\
\text { (93\%) } \\
\text { 6. Melaksanakan tugas secara } \\
\text { individu (100\%) } \\
\text { 7. Lagu/film/game }(93 \%)\end{array}$ & $\begin{array}{l}\text { 1. Abstrak } \\
\text { 2. Kosakata } \\
\text { 3. TOEFL } \\
\text { 4. Kamus teknik } \\
\text { 5. Nama alat dan bahan }\end{array}$ \\
\hline
\end{tabular}

Hasil analisis angket pada Prodi Teknik Arsitektur menunjukkan bahwa pada aspek language skills, seluruh responden (100\%) setuju bahwa pembelajaran bahasa Inggris dapat meningkatkan keterampilan mendengar (listening), berbicara (speaking), dan menulis (writing) mahasiswa. 93\% responden setuju untuk meningkatkan keterampilan membaca dalam kegiatan pembelajaran bahasa Inggris. Hal ini menunjukkan bahwa mahasiswa di Prodi Teknik Arsitektur memiliki kebutuhan belajar bahasa Inggris yang dapat meningkatkan 
keterampilan dan kompetensi bahasa Inggris mereka, terutama penguasaan bahasa Inggris yang berhubungan dengan arsitektur. Hasil analisis ini didukung oleh hasil persentase dalam aspek komponen bahasa, yakni 100\% responden menginginkan pembelajaran bahasa Inggris yang dapat meningkatkan penguasaan tata bahasa (grammar) dan kosakata (vocabulary) yang berhubungan dengan program studi mereka.

Pada aspek selanjutnya, yaitu metode dan strategi pembelajaran, sebanyak $100 \%$ atau seluruh responden setuju bahwa kegiatan pembelajaran bahasa Inggris didominasi oleh pemberian tugas-tugas atau latihan yang dapat meningkatkan penguasaan keterampilan berbahasa Inggris mereka. Selain itu, sebanyak 93\% responden setuju dengan penggunaan metode ceramah, dan penggunaan teknik pembelajaran berupa lagu, film, dan permainan. Dengan persentase yang sama juga (93\%) mereka setuju untuk dapat melaksanakan tugas secara berkelompok/berpasangan. Penggunaan teknik pembelajaran berupa lagu, film, dan permainan dianggap sangat membantu mahasiswa untuk memahami materi pembelajaran, serta dapat menciptakan suasana belajar yang menyenangkan dan menarik minat/motivasi mahasiswa untuk belajar. Hal yang menarik dalam perolehan angket ini adalah sebanyak $100 \%$ atau seluruh responden setuju untuk melaksanakan tugas secara individu. Hal ini mengindikasikan bahwa mahasiswa di Prodi Arsitektur benar-benar memiliki keinginan untuk dapat menguasai dan meningkatkan kompetensi bahasa Inggris mereka dengan cara memperbanyak pemberian tugas-tugas individu.

Untuk beberapa topik yang disarankan, responden di Prodi Arsitektur membutuhkan pembelajaran bahasa Inggris berupa latihan-latihan penulisan abstrak penelitian karena dalam penyusunan skripsi nanti mereka dituntut untuk dapat menulis abstrak penelitian dalam bahasa Inggris. Selain itu, mereka juga membutuhkan materi pengenalan TOEFL test dan teknik-teknik menjawab pertanyaan-pertanyaan dalam TOEFL test karena TOEFL test merupakan salah satu persyaratan kelulusan mereka. 
Tabel 3 Hasil Analisis Kebutuhan Belajar Mahasiswa Prodi Teknik Sipil

\begin{tabular}{|c|c|c|c|}
\hline $\begin{array}{l}\text { LANGUAGE } \\
\text { SKILLS (\%) }\end{array}$ & $\begin{array}{c}\text { LANGUAGE } \\
\text { COMPONENTS (\%) }\end{array}$ & METODE/ STRATEGI & $\begin{array}{l}\text { TOPIK YANG } \\
\text { DISARANKAN }\end{array}$ \\
\hline $\begin{array}{l}\text { Listening }(88 \%) \\
\text { Speaking }(94 \%) \\
\text { Reading }(94 \%) \\
\text { Writing }(76 \%)\end{array}$ & $\begin{array}{ll}\text { 1. } & \text { Grammar }(76 \%) \\
\text { 2. } & \text { Vocabulary } \\
\text { yang berhubungan } \\
\text { dengan prodi }(94 \%)\end{array}$ & $\begin{array}{ll}\text { 1. } & \text { Ceramah/lecture } \\
& (82 \%) \\
\text { 2. } & \text { Memberi latihan }(88 \%) \\
\text { 3. } & \text { Diskusi kelas }(88 \%) \\
\text { 4. } & \text { Bermain peran }(71 \%) \\
\text { 5. } & \text { Melaksanakan tugas } \\
\text { berkelompok/berpasa- } \\
\text { ngan }(82 \%)\end{array}$ & $\begin{array}{l}\text { 1. Struktur } \\
\text { 2. Geotek } \\
\text { 3. Keairan } \\
\text { 4. Manejemen lingkungan } \\
\text { 5. Transportasi } \\
\text { 6. Manajemen konstruksi } \\
\text { 7. Rekayasa pondasi } \\
\text { 8. Perkerasan jalan } \\
\text { 9. Manajemen proyek } \\
\text { 10. Perhitungan rab } \\
\text { 11. Mekanika bahan } \\
\text { 12. Struktur bangunan air } \\
\text { 13. Structure of wood } \\
\text { 14. Mechanic of engineering } \\
\text { 15. Structure of steel } \\
\text { 16. Planning of airport state } \\
\text { 17. Management of } \\
\text { construction }\end{array}$ \\
\hline
\end{tabular}

Pada aspek keterampilan berbahasa di angket kebutuhan belajar prodi Teknik Sipil, diperoleh hasil sebanyak 94\% responden membutuhkan pengajaran bahasa Inggris yang berorientasi pada peningkatan keterampilan berbicara dan membaca. Sebanyak $88 \%$ setuju untuk memasukkan materi listening (mendengar) dalam silabus bahasa Inggris. Sebanyak $76 \%$ setuju dengan adanya materi menulis atau writing. Hal ini menunjukkan bahwa keterampilan bahasa yang paling dibutuhkan oleh mahasiswa di Prodi Teknik Sipil adalah speaking dan reading. Dalam hal ini, pembelajaran reading diharapkan berupa pemberian latihan-latihan memahami teks-teks yang berhubungan dengan teknik sipil. Hal ini selain membantu mahasiswa memahami dan menguasai istilah-istilah yang berhubungan dengan teknik sipil, juga membantu mereka dalam menemukan dan memahami referensi berbahasa Inggris, baik referensi yang digunakan dalam mata kuliah-mata kuliah yang ada di prodi mereka maupun dalam proses penyusunan skripsi nanti. Hasil temuan ini didukung oleh persentase pada aspek komponen berbahasa yang menunjukkan bahwa sebanyak $94 \%$ atau hampir seluruh dari jumlah responden setuju untuk meningkatkan penguasaan kosakata bahasa Inggris, khususnya yang berhubungan dengan bidang ilmu mereka. Sementara itu, untuk komponen grammar ada sebanyak $76 \%$ responden menyatakan setuju untuk mempelajarinya dalam mata kuliah bahasa Inggris.

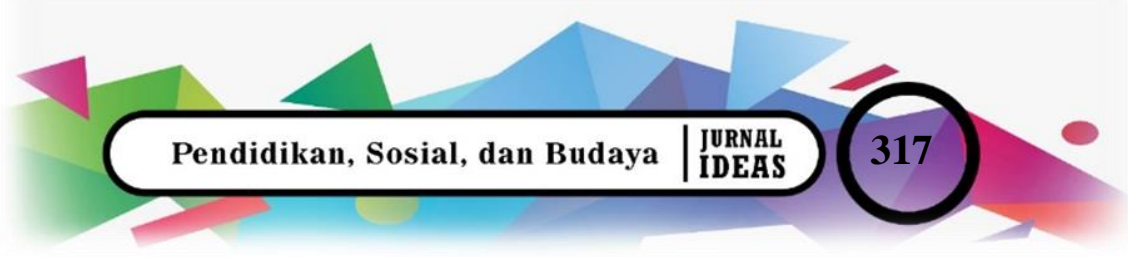




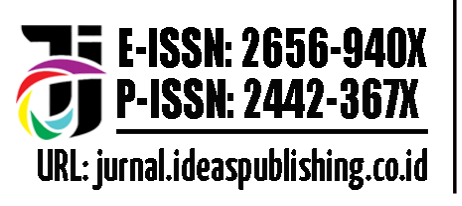

Volume : 6

Nomor : 4

Bulan : November

Tahun : 2020

Pada aspek selanjutnya, yaitu metode dan strategi pembelajaran, sebanyak $88 \%$ responden menginginkan pembelajaran bahasa Inggris dilaksanakan melalui diskusi kelas dan pemberian latihan-latihan yang dapat membantu penguasaan bahasa Inggris mahasiswa. Pelaksanaan kegiatan belajar melalui metode diskusi dapat memudahkan mahasiswa untuk melatih keterampilan berbicara mereka yaitu dengan berkomunikasi dengan teman kelompok, juga dapat memudahkan mereka memahami materi pembelajaran, karena metode diskusi memberi kesempatan kepada mahasiswa untuk menggali lebih dalam tentang materi-materi yang sedang mereka pelajari melalui diskusi dengan teman sekelas. Selain itu, sebanyak $82 \%$ mahasiswa di Prodi Teknik Sipil menginginkan pembelajaran bahasa Inggris melalui lagu, film, dan permainan. Dengan persentase yang sama, yaitu 82\%, mereka setuju bahwa kegiatan pembelajaran bahasa Inggris dilaksanakan dengan metode ceramah, dengan pemberian tugas secara individu maupun kelompok.

Tabel 4 Hasil Analisis Kebutuhan Belajar Mahasiswa Prodi Teknik Industri

\begin{tabular}{|c|c|c|c|}
\hline $\begin{array}{l}\text { LANGUAGE } \\
\text { SKILLS }(\%)\end{array}$ & $\begin{array}{c}\text { LANGUAGE } \\
\text { COMPONENTS } \\
(\%)\end{array}$ & METODE/ STRATEGI & $\begin{array}{l}\text { TOPIK YANG } \\
\text { DISARANKAN }\end{array}$ \\
\hline $\begin{array}{l}\text { Listening }(100 \%) \\
\text { Speaking }(100 \%) \\
\text { Reading }(100 \%) \\
\text { Writing }(100 \%)\end{array}$ & $\begin{array}{l}\text { 1. Grammar }(80 \%) \\
\text { 2. Vocabulary yang } \\
\text { berhubungan } \\
\text { dengan prodi } \\
(100 \%)\end{array}$ & $\begin{array}{l}\text { 1. Ceramah/lecture }(100 \%) \\
\text { 2. Memberi latihan }(93 \%) \\
\text { 3. Diskusi kelas }(67 \%) \\
\text { 4. Bermain peran }(87 \%) \\
\text { 5. Melaksanakan tugas berkelom- } \\
\text { pok/berpasangan }(100 \%) \\
\text { 6. Melaksanakan tugas secara } \\
\text { individu (80\%) } \\
\text { 7. Lagu/film/game }(87 \%)\end{array}$ & $\begin{array}{l}\text { 1. Sistem manufaktur } \\
\text { 2. Operasional } \\
\text { 3. Manajemen } \\
\text { 4. Argonomi } \\
\text { 5. TOEFL }\end{array}$ \\
\hline
\end{tabular}

Hasil analisis angket kebutuhan belajar mahasiswa Prodi Teknik Industri menunjukkan bahwa pada aspek keterampilan berbahasa sebanyak $100 \%$ atau seluruh responden setuju bahwa kegiatan pembelajaran bahasa Inggris ditekankan pada peningkatan 4 (empat) keterampilan berbahasa, yaitu mendengar, berbicara, membaca, dan menulis, serta didukung oleh peningkatan komponen berbahasa berupa pengenalan kosakata atau terminologi yang berhubungan dengan teknik industri. Pengenalan grammar atau tata bahasa Inggris disarankan dapat terintegrasi dalam kegiatan pembelajaran empat keterampilan berbahasa. Untuk komponen ini (grammar), ada sebanyak $80 \%$ responden yang setuju untuk memasukannya ke dalam kegiatan pembelajaran. 
Volume : 6

Nomor : 4

Bulan : November

Tahun : 2020
E-ISSH: 2656-940X

P-ISSH: 2442-367K

URL: jurnalideaspublishing.co.id

Hasil analisis kebutuhan penggunaan metode/strategi pembelajaran menunjukkan bahwa sebanyak $100 \%$ atau seluruh responden setuju untuk mempelajari bahasa Inggris dengan metode ceramah dan melaksanakan tugas secara berkelompok/berpasangan. Selain itu, sebanyak 93\% responden ingin pembelajaran bahasa Inggris ditekankan pada pelaksanaan tugas/latihan yang dapat membantu meningkatkan kompetensi bahasa Inggris mereka, serta menguji pemahaman mereka terhadap materi yang telah diajarkan oleh dosen. Yang terakhir adalah sebanyak $87 \%$ responden setuju untuk mempelajari bahasa Inggris melalui lagu, film, dan permainan, juga metode bermain peran. Penggunaan metode-metode ini sangat bermanfaat untuk mengasah keterampilan berbahasa Inggris, serta meningkatkan minat dan motivasi belajar mahasiswa.

Salah satu topik yang disarankan dalam silabus adalah materi tentang pengenalan TOEFL test. Selain dapat digunakan untuk dunia kerja nanti, hasil TOEFL test juga menjadi salah satu syarat bagi mahasiswa Prodi Teknik Industri untuk mengikuti ujian skripsi nanti. Sehingganya, mata kuliah bahasa Inggris diharapkan menjadi sarana bagi mahasiswa untuk mengenali TOEFL test juga mengetahui berbagai teknik menjawab soal-soal dalam TOEFL test.

Tabel 5 Hasil Analisis Kebutuhan Belajar Mahasiswa Prodi Teknik Informatika

\begin{tabular}{|c|c|c|c|}
\hline $\begin{array}{l}\text { LANGUAGE } \\
\text { SKILLS (\%) }\end{array}$ & $\begin{array}{c}\text { LANGUAGE } \\
\text { COMPONENTS }(\%)\end{array}$ & METODE/ STRATEGI & $\begin{array}{l}\text { TOPIK YANG } \\
\text { DISARANKAN }\end{array}$ \\
\hline $\begin{array}{l}\text { Listening }(91 \%) \\
\text { Speaking }(82 \%) \\
\text { Reading }(91 \%) \\
\text { Writing }(82 \%)\end{array}$ & $\begin{array}{l}\text { 1. Grammar }(82 \%) \\
\text { 2. Vocabulary yang } \\
\text { berhubungan dengan } \\
\text { prodi }(91 \%)\end{array}$ & $\begin{array}{l}\text { 1. Ceramah/lecture }(73 \%) \\
\text { 2. Memberi latihan }(91 \%) \\
\text { 3. Diskusi kelas }(91 \%) \\
\text { 4. Bermain peran }(82 \%) \\
\text { 5. Melaksanakan tugas berkelom- } \\
\text { pok/berpasangan }(100 \%) \\
\text { 6. Melaksanakan tugas secara } \\
\text { individu }(100 \%) \\
\text { 7. Lagu/film/game }(100 \%)\end{array}$ & $\begin{array}{l}\text { 1. Simbada } \\
\text { 2. Pemweb } \\
\text { 3. Presentasi } \\
\text { 4. Public speaking } \\
\text { 5. Artikel/makalah } \\
\text { ilmiah }\end{array}$ \\
\hline
\end{tabular}

Angket kebutuhan belajar mahasiswa di Prodi Informatika menunjukkan bahwa sebanyak $91 \%$ responden setuju untuk meningkatkan keterampilan mendengar dan membaca dalam kegiatan pembelajaran bahasa Inggris. Perolehan ini lebih tinggi dibanding persentase pada keterampilan berbicara dan menulis yang memperoleh sebanyak $82 \%$ responden yang menyetujuinya. Bagi mahasiswa Teknik Informatika, materi dan latihan reading teks-teks berbahasa Inggris sangat bermanfaat bagi mereka untuk memahami referensi-referensi berbahasa Inggris yang mereka gunakan dalam kegiatan pembelajaran juga dalam penyusunan

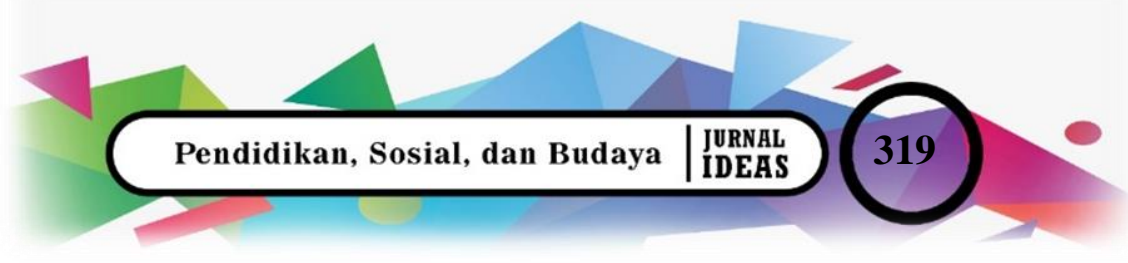


skripsi nanti. Selain itu, responden di jurusan ini juga ingin meningkatkan penguasaan kosakata yang berhubungan dengan prodi mereka. Hal ini ditujukkan dengan persentase sebanyak $91 \%$ responden yang setuju dengan pembelajaran vocabulary dalam silabus mata kuliah

bahasa Inggris.

Untuk aspek metode/strategi pembelajaran, sebanyak 100\% atau seluruh responden setuju dan menginginkan pembelajaran bahasa Inggris melalui lagu, film, dan game, serta melaksanakan tugas secara individu maupun berkelompok/berpasangan. Kegiatan pembelajaran lain yang diinginkan adalah berupa diskusi kelas, pemberian latihan-latihan yang dapat meningkatkan kompetensi bahasa Inggris mahasiswa, dan bermain peran. Persentase paling rendah adalah pada penggunaan metode ceramah, yakni hanya $73 \%$ dari jumlah responden yang menyetujuinya. Hasil persentase pada aspek ini menunjukkan bahwa mahasiswa di Prodi Teknik Informatika ingin pembelajaran bahasa Inggris lebih ditekankan pada pemberian latihan/tugas dibanding pemberian ceramah mata kuliah.

Pada topik yang disarankan, sebagian besar responden menginginkan adanya latihan presentasi dan public speaking dalam bahasa Inggris, serta latihan penulisan karya tulis ilmiah. Pemberian materi-materi ini dianggap penting karena sebagian mahasiswa Teknik Informatika aktif ikut serta dalam berbagai lomba bahasa Inggris, seperti debat, mawapres, penulisan karya tulis ilmiah, dan lomba-lomba lainnya.

\section{Simpulan}

Mata kuliah bahasa Inggris merupakan salah satu mata kuliah wajib di semua program studi yang ada di UNG. Pembelajaran bahasa Inggris di prodi-prodi tersebut bertujuan untuk membekali mahasiswa dengan keterampilan berbahasa Inggris yang nantinya dapat membantu dan mempermudah mereka dalam proses belajar mata kuliah-mata kuliah khusus yang ada di program studi (prodi) mereka, terlebih bagi prodi-prodi yang banyak menggunakan terminologi bahasa Inggris dalam proses pembelajarannya. Selain itu, untuk manfaat jangka panjangnya, bekal kemampuan berbahasa Inggris dapat menunjang dan menciptakan lulusan berkualitas dan mampu bersaing dalam dunia kerja. Berdasarkan hal ini, maka dibutuhkan proses pembelajaran yang benar-benar disesuaikan dengan kebutuhan belajar bahasa Inggris mahasiswa. 


Volume : 6
Nomor : 4
Bulan : November
Tahun : 2020

Volume : 6

Bulan : November

Tahun : 2020
E-ISSH: 2656-940X

P-ISSH: 2442-367K

URL:jurnal.ideaspublishing.co.id

Penelitian ini bertujuan untuk menganalisis kebutuhan belajar bahasa Inggris pada mahasiswa di lima program studi yang ada di fakultas teknik Universitas Negeri Gorontalo, yaitu prodi Elektro, Arsitektur, Sipil, Industri, dan Informatika. Berdasarkan hasil analisis angket diperoleh jawaban bahwa mahasiswa di lima prodi tersebut memiliki kebutuhan belajar bahasa Inggris yang dititikberatkan pada peningkatan empat keterampilan bahasa, yaitu berbicara, menulis, mendengar, dan membaca. Keempat keterampilan ini memperoleh persentase antara 90\% dan 95\%, yang menunjukkan bahwa pembelajaran empat keterampilan berbahasa Inggris ini sama pentingnya bagi mereka dalam peningkatan kualitas diri, membantu proses pembelajaran mata kuliah-mata kuliah lain yang ada di prodi mereka, serta untuk bekal masa depan mereka. Selain itu, mereka butuh diberi banyak latihan-latihan yang dapat meningkatkan penguasaan kosakata bahasa Inggris, terutama kosakata yang relevan dengan prodi tempat mereka belajar. Mahasiswa di fakultas teknik juga memiliki harapan dapat belajar bahasa Inggris dengan topik-topik tertentu yang sesuai dengan kebutuhan mereka, seperti TOEFL, penulisan abstrak berbahasa Inggris, cara menulis karya ilmiah berbahasa Inggris, presentasi berbahasa Inggris, dan public speaking.

Melalui penelitian ini, diharapkan akan tercipta sebuah silabus pembelajaran bahasa Inggris dengan materi yang mengacu pada kebutuhan belajar mahasiswa. Hasil analisis kebutuhan belajar mahasiswa ini yang kemudian akan menjadi ide pokok dari setiap topik pembelajaran. Dengan begitu, mahasiswa benar-benar akan merasakan manfaat dari pembelajaran bahasa Inggris hingga akhir studi mereka.

Hasil penelitian ini juga diharapkan dapat menjadi acuan bagi dosen pengajar dalam menyusun silabus dan bahan ajar mata kuliah bahasa Inggris di prodi-prodi yang ada di fakultas teknik UNG. Karena mata kuliah ini hanya diperoleh mahasiswa di satu semester saja, maka diharapkan bekal ilmu yang diperoleh mahasiswa dalam mata kuliah ini benarbenar sesuai dengan kebutuhan belajar mereka, serta dapat memberi manfaat baik jangka pendek maupun jangka panjang bagi mereka. 


\section{Daftar Pustaka}

Aflah, Mita Nur \& Rahmani, Eka Fajar. (2018). "Analisis Kebutuhan (Need Analysis) Mata Kuliah Bahasa Inggris untuk Mahasiswa Kejuruan”. Jurnal Pendidikan Bahasa, 7(1).

Casper, A. (2003). http://linguistic.byu.edu/TESOLBYU.NeedsAnalysis.htm.

Kusumaningputri, Reni. (2010). "English for Specific Purposes di Universitas Negeri Jember: Tantangan dan Solusi”. Jurnal Pengembangan Pendidikan, 1(1).

Mohammed, Ahmad. (2012). International Journal of Academic Research in Business and Social Sciences. 2(11). ISSN: 2222-6990.

Sari, Rita Karmila. (2019). "Analisis Kebutuhan Pembelajaran Bahasa Inggris pada Mahasiswa Kelas Karyawan”. SAP (Susunan Artikel Pendidikan), 4(1). 
Volume : 6

Nomor : 4

E-ISSH: 2656-940X

Bulan : November

Tahun : 2020

P-ISSH: 2442-367K

URL: jurnal.ideaspublishing.co.id 